\title{
Etfect of Oral Administration of Copper Sulphate to Mice
}

\author{
Ryohei KOJIMA and Eiko TANAKA \\ Institute for Higiene and Medical Microbiology of Toyama, Toyama
}

(Accepted for publication : May 24, 1973)

In mice oral administration of cadmium (Cd) resulted the increase of copper ( $\mathrm{Cu}$ ) concentration in kidneys as well as Cd concentration. To investigate the effect of $\mathrm{Cu}$ administration $\mathrm{CuSO}_{4}$ at concentrations ranging from 0.006 to $1.6 \%$ was orally administered to dd mice via drinking water for 15 days. No remarkable toxicity was observed at a concentration of $0.2 \%$ or less, whereas slight and moderate toxicities were observed at 0.4 and $0.8 \%$, respectively. A concentration of $1.6 \%$ was lethal. Tolerable concentration of $\mathrm{Cu}$ in the mouse liver was found to be approximately 4 times higher than that of the normal level. Relationship between the Cu concentration in drinking water and changes in body weight, bone weight, skin thickness and blood cell counts as well as changes in $\mathrm{Cu}$ and other heavy metal concentrations were discussed.

[Exp. Animals, 22 (3), 247-250, 1973]

\section{硫酸銅経口投与のマウスに及ぼす影響 \\ 小島良平 - 田中英子 富山県衛生研究所}

著者らはさきにカドミウムを動物に経口的に与えると 臓器内の $\mathrm{Cu}$ 抢よび $\mathrm{Zn}$ など他の重金属の分布に変化が おこることを観察した[1]。Cd と Cu の併用投与実験に 先立って，マウスに硫酸銅を経口投与し，その毒性と $\mathrm{Cu} \cdot \mathrm{Zn}$ および $\mathrm{Cd}$ の臓器内分布の変化について観察し た。

\section{材 料と方 法}

動物：体重 $20 \pm 1 \mathrm{gr}$ の dd 系雄マウスを 1 群 5 匹として 実験を行った。餌としてオリエンタル 酵母の 固型飼料 MF を自由に摂取せしめた。

硫酸銅：蒸留水で1.6\%以下倍々稀釈し，0.006\%までの 各濃度のものをそれぞれガラスの給水ビンから自由に捸 取させた。対照群には水道水を摂取させた。 摄水量：はじめの 4 日間の摂水量を測定し $\mathrm{ml} /$ 日/匹の 值を算出した。
体重 : 村上式体重計で 5 日ごとに15日まで測定した。 尿検查：0日と15日にコンビスチィクス（エームス社） で糖と蛋白の検査をした。

皮膚の厚さ：実験終了時背正中部の肩甲骨よりやや尾側 をつまみ上げ，ノギスで厚さを測定した（皮下脂肪を含 め皮膚の厚さの 2 倍を測っている)。

蔵器重量 : 実験終了後(15日), クロロホルムで動物を殺 し，肝・腎・脾ならびそ右大腿骨を摘出しメトラー天秤 で測定した。

血液所見：15日にノイバウエル氏血算板を用いて赤血球 数を, たたシアンメトへモグロビン法（和光純薬キット 使用）でへモグロビン值の測定を行い血色素係数を算出 した。

重金属濃度測定：一群の各臓器をプールして藏器別に前 報〔1]の記載に従って湿式分解後, APDTC 法で重金属 を抽出し, 日立 208 型原子吸光装置を用いて $\mathrm{Cu} \cdot \mathrm{Zn}$ 及 び Cd の濃度を測定した。 
Table 1. Protein cocentration in urine

成

体重変化（図 1 ）をみると, 硫酸銅濃度が $0.2 \%$ ほ下 では一過性の発育促進がみられたが，0.1\%以下では 5 日目に，0.2\%では 10 日目に対照群よりも増加の傾向が みられた。0.4\%以上では濃度に応じて体重減少がみら れた。0.4\%では10日目に体重は回復したが，0.8\%では 15日目でも回復せず，1.6\%では体重は減少を続けなが ら17日目に全例死亡した。

尿糖は全例院性であり，尿蛋白は表 1 に示したよう に，対照群に比べ $\mathrm{CuSO}_{4}$ 投与群は全て $(+)$ 以上の陽性 を示し，0.1ないし $0.2 \%$ な゙は（十）のみを示す傾向がみ られ，0.8\%以上で (H) を示す個体がみられた。

剖見時の体重, 臟器重量, 皮膚の厚さ（皮厚と略す） を表 2 にまとめた。体重は $0.025 〜 0.05 \%$ の $\mathrm{Cu}$ 濃度を 除き, 濃度に応じて減少の傾向を示した。この内容を更 に分析するために臟器別にみると，肝蔵は $0.006 \%$ でや

\begin{tabular}{lllll}
\hline $\mathrm{CuSO}_{4}$ & \multicolumn{4}{c}{ Protein concentration* } \\
concentration & \pm & + & +- & ++ \\
\hline 1.6 & 0 & 0 & 0 & 1 \\
0.8 & 0 & 4 & 0 & 1 \\
0.4 & 0 & 3 & 1 & 0 \\
0.2 & 0 & 5 & 0 & 0 \\
0.1 & 0 & 5 & 0 & 0 \\
0.05 & 0 & 2 & 1 & 0 \\
0.025 & 0 & 3 & 0 & 0 \\
0.012 & 0 & 3 & 2 & 0 \\
0.006 & 0 & 4 & 1 & 0 \\
Control & 3 & 2 & 0 & 0 \\
\hline
\end{tabular}

(See Figur 1)

* Tested with Combistics (Ames Co., LTD.)

や肥大し，0.2\%以上では濃度上昇に伴って減少し $0.8 \%$ では64\%となった。腎藏は0.05\%においてわずかに増加 を示し，0.8\%で対照の79\%に低下した。脾臟は0.2\%ま

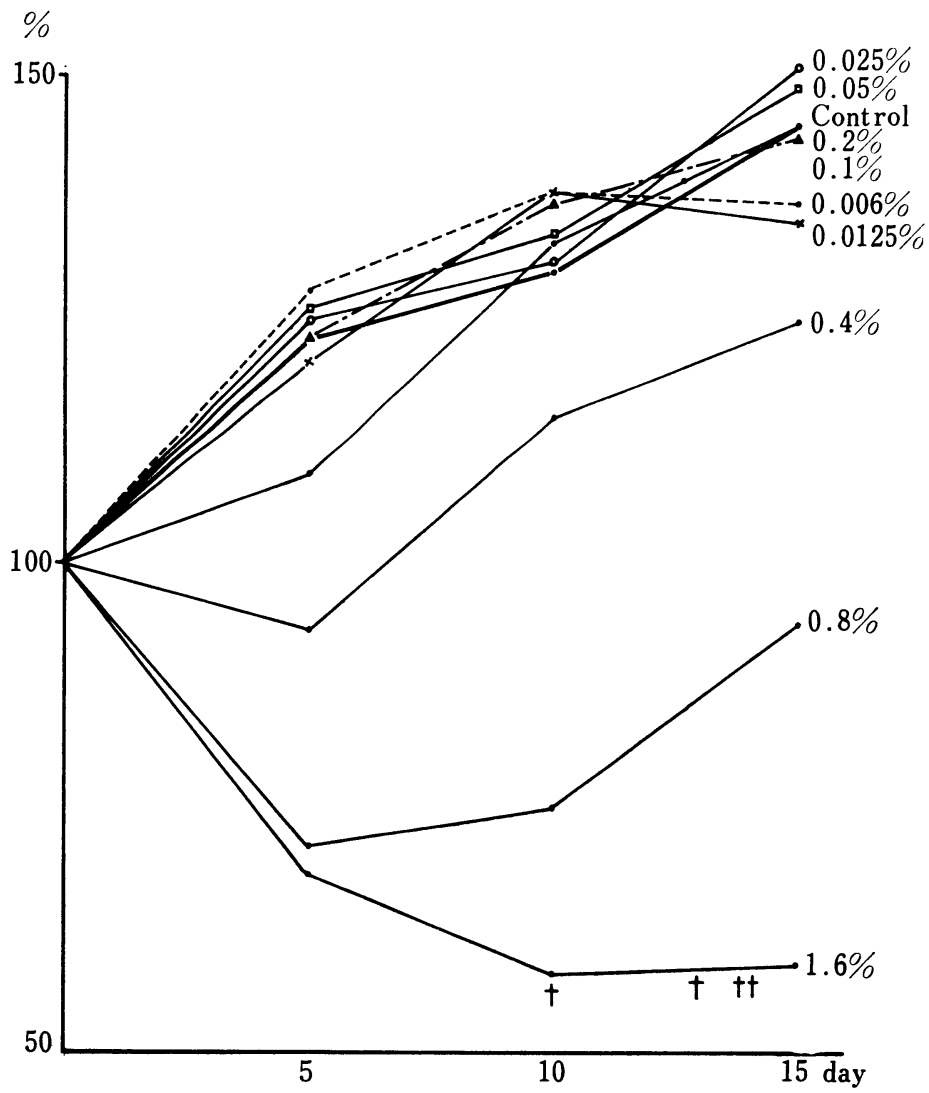

Fig. 1 Body wlight changes 
での間は $\mathrm{Cu}$ 濃度と平行した重量増加がみられ，0.8\% に叔いては86\%の重量を示した。骨重量は0.006〜0.012 \%でごくわずかに減少し，また $0.8 \%$ に执いて $80 \%$ の重 量比を示したが，それ以外は殆ど対照群と変らなかっ た。なお $0.025 〜 0.05 \%$ 群に括ける後腹壁の脂肪沈着は 対照群より良好であった。

皮厚は 0.006 〜 $0.012 \%$ でわずかに減少し0.025\%で対 照群と等しくなったのち再び減少し $0.8 \%$ では対照群の 70\%を示すようになった。

赤血球数並びにへモグロビン量を表 3 に示す。 $\mathrm{Cu}$ 濃 度にかかわらずへモグロビン量はほぼ $16 \mathrm{~g} / \mathrm{d} l$ 前後に保 たれており, 赤血球は $0.05 \%$ でやや增加し以後対照群と 同じ值にもどる傾向を示した。血色素係数も著しい変動 は示さなかったが $1.6 \%$ に達すると明らかに低值を示し た。
各臓器内重金属濃度を表 4 亿まとめた。Cu について みると肝では $\mathrm{CuSO}_{4} \quad 0.2 \%$ で16.3 $\mathrm{\gamma} / \mathrm{g}$ と対照群の約 4 倍となり $0.8 \%$ では $178.4 \mathrm{r} / \mathrm{g}$ と著しく高い值を示した。 腎では0.012\%で $12.5 \mathrm{r} / \mathrm{g}$ と高值を示し, 以後 $\mathrm{Cu}$ 濃度 が上昇しても対照群と大差ない值にもどるのがみられ た。骨では Cu は全く検出されなかった。Zn について は肝臟で $\mathrm{Cu}$ 濃度の高くなるにつれてわずかな增加が認 められたのみであり, 腎では0.012\%で 23.9 r/g とごく わずか増加したのみであった。骨に拈いては $\mathrm{CuSO}_{4}$ 0.05ないし0.2\%でやや $\mathrm{Zn}$ 含量の増加を示した。Cd 関しては骨では全く検出されず腎臟では $\mathrm{CuSO}_{4} 0.8 \%$ 群のみ $1.5 \mathrm{r} / \mathrm{g}$, 肝臟では $\mathrm{CuSO}_{4} 0.006 \%$ 投与群のみ 0.3 $\gamma / \mathrm{g}$ 検出された。 $\mathrm{Zn} / \mathrm{Cu}$ は肝臟では $\mathrm{CuSO}_{4}$ 濃度上昇に つれて減少した他, 腎の $0.012 \%$ 投与群において低值を 示すのが注目された。

Table 2. Body Weight, Skin-thickness and Organ weight

\begin{tabular}{|c|c|c|c|c|c|c|}
\hline \multirow{2}{*}{$\begin{array}{c}\mathrm{CuSO}_{4} \\
\text { concentration }\end{array}$} & \multirow{2}{*}{$\begin{array}{l}\text { Body } \\
\text { weight }\end{array}$} & \multirow{2}{*}{$\begin{array}{l}\text { Skin } \\
\text { thickness }\end{array}$} & \multicolumn{4}{|c|}{ Organ Weight } \\
\hline & & & Liver & $\begin{array}{l}\text { Kidney } \\
\text { (bose) }\end{array}$ & Spleen & r-Femur \\
\hline $1.6 \%$ & $\left(\begin{array}{l}12 \\
40)\end{array}\right.$ & $\begin{array}{l}0.8 \\
(60)\end{array}$ & & & & \\
\hline 0.8 & $\left(\begin{array}{l}19.2 \\
63)\end{array}\right.$ & $\begin{array}{l}0.94 \\
(70)\end{array}$ & $(64)^{1.190}$ & $\left(\begin{array}{l}0.437 \\
(79)\end{array}\right.$ & $(86)^{0.101}$ & $(80)^{0.110}$ \\
\hline 0.4 & $\left(\begin{array}{l}26.0 \\
86)\end{array}\right.$ & $(84)^{1.12}$ & & & & \\
\hline 0.2 & $\begin{array}{l}29.9 \\
(99)\end{array}$ & $(93)^{1.24}$ & $\left({ }^{1.69)}\right)^{651}$ & $\left(\begin{array}{l}0.536 \\
(96)\end{array}\right.$ & $\left.{ }^{(136)}\right)^{0.160}$ & $\begin{array}{c}0.133 \\
(97)\end{array}$ \\
\hline 0.1 & $\begin{array}{l}29.6 \\
(98)\end{array}$ & $(79)^{1.06}$ & & & & \\
\hline 0.05 & $\begin{array}{c}31.0 \\
(104)\end{array}$ & $(94)^{1.26}$ & $\left(^{101)^{883}}\right.$ & $\begin{array}{c}0.611 \\
(110)\end{array}$ & ${ }^{0.130}$ & $\begin{array}{c}0.139 \\
(101)\end{array}$ \\
\hline 0.025 & $\begin{array}{l}31.5 \\
(104)\end{array}$ & $(100)^{1.34}$ & & & & \\
\hline 0.0125 & $\begin{array}{l}27.9 \\
(92)\end{array}$ & $(87)^{16}$ & $(96)^{1.776}$ & $\begin{array}{l}0.562 \\
(101)^{-}\end{array}$ & $\begin{array}{l}0.126 \\
(107)^{-12}\end{array}$ & $(95)^{0.130}$ \\
\hline 0.006 & $\begin{array}{l}27.9 \\
(92)\end{array}$ & $(84)^{1.12}$ & ${ }_{(115)}^{2.136}$ & $\left(\begin{array}{l}0.549 \\
(99)\end{array}\right.$ & ${ }_{(104)}^{0.123}$ & $\left(\begin{array}{c}0.130 \\
(95)\end{array}\right.$ \\
\hline Control & $\begin{array}{c}30.3 \\
(100)\end{array}$ & $(100)^{1.34}$ & ${ }_{(100)}^{1.857}$ & ${ }_{(100)}^{0.556}$ & ${ }_{(100)}^{0.118}$ & ${ }_{(100)}^{0.137}$ \\
\hline
\end{tabular}

Table 3. Blood observation

\begin{tabular}{lccc}
\hline $\begin{array}{c}\mathrm{CuSO}_{4} \\
\text { concentration }\end{array}$ & $\begin{array}{c}\text { No. Erythrocyte } \\
10^{4} / \mathrm{mm}^{3}\end{array}$ & $\begin{array}{c}\mathrm{Hb} \\
\mathrm{g} / \mathrm{d} l\end{array}$ & Color Index \\
\hline $1.6 \%$ & 1235 & 15.5 & 0.39 \\
0.8 & 965 & 15.9 & 0.51 \\
0.2 & 983 & 15.7 & 0.50 \\
0.05 & 1060 & 16.2 & 0.48 \\
0.0125 & 1036 & 16.4 & 0.50 \\
0.006 & 980 & 16.1 & 0.51 \\
Control & 933 & 15.9 & 0.53 \\
\hline
\end{tabular}


Table 4. Changes of heavy metal concentration in organs

\begin{tabular}{|c|c|c|c|c|c|c|c|}
\hline \multirow{2}{*}{\multicolumn{2}{|c|}{ Metals Organs }} & \multicolumn{6}{|c|}{$\mathrm{CuSO}_{4}$-concentration $(\%)$} \\
\hline & & 0.8 & 0.2 & 0.05 & 0.0125 & 0.006 & Control \\
\hline \multirow[t]{3}{*}{$\mathrm{Cu}$} & Liver & $178.4^{*}$ & $16.3^{*}$ & $5.7 *$ & $4.2^{*}$ & $3.8^{*}$ & $4.0^{*}$ \\
\hline & Kidney & 4.4 & 3.4 & 2.8 & 12.5 & 3.0 & 3.7 \\
\hline & Bone & 0 & 0 & 0 & 0 & 0 & 0 \\
\hline \multirow[t]{3}{*}{$\mathrm{Zn}$} & Liver & 37.2 & 33.9 & 31.0 & 29.8 & 25.1 & 24.7 \\
\hline & Kidney & 19.8 & 19.7 & 17.3 & 23.9 & 20.0 & 19.6 \\
\hline & Bone & 7.9 & 26.8 & 21.0 & 6.5 & 19.5 & 14.0 \\
\hline \multirow[t]{3}{*}{$\mathrm{Cd}$} & Liver & 0 & 0 & 0 & 0 & 0.3 & 0 \\
\hline & Kidney & 1.5 & 0 & 0 & 0 & 0 & 0 \\
\hline & Bone & 0 & 0 & 0 & 0 & 0 & 0 \\
\hline \multirow[t]{3}{*}{$\mathrm{Zn} / \mathrm{Cu}$} & Liver & 0.2 & 2.0 & 5.4 & 7.1 & 6.6 & 6.8 \\
\hline & Kidney & 4.5 & 5.8 & 6.2 & 1.9 & 6.6 & 5.3 \\
\hline & Bone & $\infty$ & $\infty$ & $\infty$ & $\infty$ & $\infty$ & $\infty$ \\
\hline
\end{tabular}

$* \mu \mathrm{g} / \mathrm{gr}$ wet weight

\section{考察}

体重の変化からして, 経口投与した $\mathrm{CuSO}_{4}$ の濃度が $0.2 \%$ 以下では著明な毒性はみられないが， $0.4 \%$ 軽 度， $0.8 \%$ では中等度，1.6\%では致死的な毒性が認めら れた。

$\mathrm{CuSO}_{4}$ 0.4\%以上では, 体重, 皮厚ともに著しく低下 した。皮厚は体重とともに健康の良いバロメーターであ る。一方 $\mathrm{CuSO}_{4} 0.4 \%$ 以下の場合皮厚は骨重量よりも より鋭敏な反応を示した。

臟器内の重金属分布で最も著しい変化を示したのは肝 臓内の $\mathrm{Cu}$ であった。 $\mathrm{CuSO}_{4} 0.2 \%$ 投与群の肝内 $\mathrm{Cu}$ 濃 度が対照群の約 4 倍を示し， $0.8 \%$ では異常に高い $\mathrm{Cu}$ 值を示していることからして, 正常值の約 4 倍の $\mathrm{Cu}$ は 肝臓の適応限界であり, $\mathrm{CuSO}_{4} 0.2 \%$ 経口投与に拈け る急性毒性を示さぬ限界と思われる。 $\mathrm{CuSO}_{4}$ 0.4\%では 軽度， $0.8 \%$ では中等度，16\%ではほぼ $\mathrm{LD}_{100}$ の毒性を 示すことが証明された。

腎藏および骨に拈ける $\mathrm{Cu}$ 濃度は肝臓に比べると低か ったが， $0.012 \%$ で腎 $\mathrm{Cu}$ がやや高值を示し，蛋白尿も
やや増加し, 体重, 皮厚, 骨重量ともに低下しているの は興味深い。腎障害があり，骨もその影響をこうむって いることがうかがわれる。

骨に拈ける $\mathrm{Cu}$ 濃度は極めて低かったが， $\mathrm{Cu}$ 投与に よる Zn の変化が骨では認められた。0.012\%と0.8\%に おいて Zn 濃がそれぞれ 6.5 および 7.9 r/g と低下し， 0.05〜0.2\%において $\mathrm{Zn}$ 值の上昇がみられたことは， 前報〔1]の $\mathrm{Cd}$ 投与による骨の $\mathrm{Zn}$ 值の低下を考えあわ せると興味深い。

$\mathrm{CuSO}_{4} \quad 0.8 \%$ 以上では尿蛋白の増加（H）傾向が認め られ，腎機能低下が示唆された。一方 $\mathrm{CuSO}_{4} 0.4 \%$ 以 下で血液所見が比較的よく保たれていたのは，骨におけ る $\mathrm{Cu}$ 濃度が低く，腎障害も軽度であったためであろ ら。

久保田憲太郎所長に校閲をたまわり感謝いたします。

文献

［1]小島良平・田中英子 - 久保田憲太郎（1972）：医 学と生物学 $85,285-290$ 